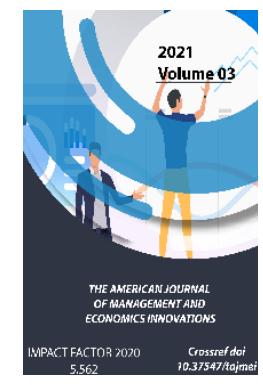

\title{
Formation And Development Of The Labor Market In Uzbekistan
}

\author{
Tuxta Daminovich Mamatkulov \\ Lecturer, Termez State University, Uzbekistan
}

Journal Website:

http://theamericanjour

nals.com/index.php/taj

mei

Copyright: Original

content from this work

may be used under the

terms of the creative

commons attributes

4.0 licence.

\section{ABSTRACT}

This article describes the formation and development of the labor market in Uzbekistan, its state. Unemployment caused by pandemic restrictions and measures taken to eliminate it and mitigate the situation were analyzed. It also covers the ongoing reforms to ensure the stability of the labor market. International experience has been studied, problems in providing employment have been identified and directions for overcoming them have been suggested.

\section{KEYWORDS}

Labor, labor market, unemployment, employment, demographic factors, demographic changes.

\section{INTRODUCTION}

The coronavirus pandemic has limited the ability of millions of people to work. With the introduction of quarantine measures in the world, the activities of unnecessary firms and enterprises have been suspended. As a result of the introduced quarantine measures, the demand for goods and services in the domestic and foreign markets has significantly decreased.

In the context of the aggravation and danger of such socio-economic processes,
Uzbekistan, along with many other countries, has taken and continues to take measures to support the population. In particular, priority is given to public health, assistance to the unemployed, entrepreneurs. In particular, the Anti-Crisis Fund with a fund of 10 trillion soums was established, which was directed to the financial support of health, social infrastructure, the population and businesses. In 2020, about 34 trillion soums of benefits were provided to more than 500,000 
entrepreneurs and more than 8 million citizens, 2.6 trillion soums were allocated for social benefits, financial assistance and employment.

Today, the country is carrying out reforms to ensure employment, in particular, the widespread introduction of the mechanism of self-employment and support for its development, improving the legal framework. In particular, in order to regulate relations in the field of employment, on October 20, 2020, the Law of the Republic of Uzbekistan "On Employment" No. ZRU-642 was adopted.

With this document, a number of issues related to employment were identified at the legislative level. Including:

- Allocation of subsidies, grants and loans to stimulate employment and attract entrepreneurship;

- Formation of the annual state order on job creation;

- Types of services provided by local labor authorities to job seekers and unemployed people;

- Procedure for registration and deregistration of job seekers by local labor authorities;

- Maintenance of the interdepartmental software and hardware complex "Single National Labor System";

- Electronic record of length of service.

- It is no exaggeration to say that all this is the beginning of reforms aimed at simplifying and supporting the processes of formation, development, regulation, employment and self-employment of the labor market in Uzbekistan, which has a growing population.

\section{LITERATURE REVIEW}

In general, the economic function of the labor market is to rationally attract, distribute, regulate and use labor (Korzhova, 2015).

Demand and supply of labor in the labor market have a special place in the population, its composition by sex and age, birth rate, ie demographic factors. In particular, it is possible to highlight several factors of the impact of demographic factors on employment (Yakovets, 2003):

First, population growth is forcing people to look for new areas to live in;

Secondly, depending on the density of the population, there are different demographic pressures on nature: the attraction of natural resources to production and their consumption increases, the environment is polluted.

The change in the demographic factor is a global problem that in many ways determines the state and development of a society. At the beginning of the XXI century, the most important demographic features of the world are the decline in birth rates and the aging of the population. This is especially true in industrialized countries. In general, the world's population is aging rapidly, and this has a serious impact on health and pension authorities, as well as government spending on the social sphere (Abdurahmonova, 2013).

In addition, the following factors affecting the labor market should be mentioned (Stytsyuk, 2014): 
- General state of the national economy;

- Salary growth;

- A priority for some professions or, conversely, a decline in the prestige of any profession;

- Changes in the demographic situation in the country;

- Changes in the leisure of the population.

An important condition for the formation and development of labor market infrastructure is the formation of a labor market information system that provides communication between its subjects (Arabov, 2017). Therefore, the information should be as accurate as possible and complete enough to conduct research in the labor market, to reflect the processes taking place in it, it not only describes the state of the labor market, but also serves as a basis for forecasting the processes under study. strengthen the changes that will occur as a result of the implementation of measures (Umarova, 2019). Aggregate data make changes in economic growth seem fairly small. In developed countries economic growth rarely tops $3 \%$, but such figures conceal a more tumultuous reality (Henrekson, 2014).

The development of labor market infrastructure depends on the effectiveness of the structures of its system that promote employment of the entire population (Kholmominov et al., 2016).

\section{RESEARCH METHODOLOGY}

The study used methods such as economic, statistical, comparative analysis, and logical reasoning. Also, published scientific works of local and foreign scientists on this topic, as well as official statistics of the Statistics
Committee of the Republic of Uzbekistan and the Ministry of Employment and Labor Relations.

\section{ANALYSIS AND RESULTS}

Measures taken to maintain employment and reduce unemployment in Uzbekistan during the pandemic, when the highest unemployment rate returned (Yunusov, 2020). Including:

1. Parents quarantined in connection with coronavirus infection or suspected of being infected (their surrogates, guardians, trustees), as well as those caring for their children under 14 years of age are entitled to a temporary disability pension of 100 percent of the average monthly salary;

2. It is prohibited to terminate employment contracts at the initiative of the employer with employees who are infected with coronavirus infection or quarantined, as well as the parents (substitutes, guardians, trustees) of a child under 14 years of age;

3. Ensuring timely payment of salaries to employees of preschool, general secondary, secondary special and higher education institutions, sports and cultural institutions (1.04 million people) financed from the state budget and suspended their activities;

4. In addition, the amount of financial assistance paid to the employee, which is not subject to personal income tax, was increased from 4.22 to 7.5 times the minimum wage;

5. A simplified system of providing the population with documents on 
temporary incapacity for work was introduced;

6. Annual leave (including those who have worked less than 6 months) presented;

7. It is established that employers may transfer employees, especially pregnant women, the elderly, people with disabilities and people with chronic diseases, with their consent, to a remote work method, a convenient work schedule or work from home;
8. During the period when medical, sanitary-epidemiological and other staff are involved in measures to combat the spread of coronavirus infection, daily additional payments of $6 \%$ of their monthly salary have been introduced.

The address of the President of the Republic of Uzbekistan to the Oliy Majlis sets priorities for 2021 (Figure 1).

\begin{tabular}{|c|c|c|c|}
\hline \multicolumn{2}{|c|}{ Maintaining a single electronic "Social Register" } & \multicolumn{2}{|c|}{ Establishment of vocational training centers } \\
\hline \multicolumn{2}{|c|}{ Determining the amount of consumer spending } & \multicolumn{2}{|c|}{$\begin{array}{l}\text { Subsidy to training centers up to } 1 \text { million } \\
\text { soums per person }\end{array}$} \\
\hline \multicolumn{2}{|c|}{$\begin{array}{l}\text { "Motivation, skills and financial support" - a new } \\
\text { mechanism: }\end{array}$} & \multicolumn{2}{|c|}{$\begin{array}{c}\text { Subsidizing up to } 7 \text { million soums for graduates } \\
\text { of training centers }\end{array}$} \\
\hline \multicolumn{2}{|c|}{$\begin{array}{l}\text { New system for employment and poverty reduction } \\
\text { of the needy population: }\end{array}$} & \multicolumn{2}{|c|}{$\begin{array}{c}\text { Allocation of } 10 \text { sots to } 1 \text { hectare of land to } \\
\text { farming families }\end{array}$} \\
\hline $\begin{array}{c}\text { Promotion of } \\
\text { employment and } \\
\text { transfer of } 500 \\
\text { billion soums from } \\
\text { public works funds }\end{array}$ & $\begin{array}{l}3 \text { times increase in } \\
\text { temporary } \\
\text { unemployment } \\
\text { benefits }\end{array}$ & $\begin{array}{l}\text { ork carried out } \\
\text { egions should } \\
\text { ler the control } \\
\text { hambers of the } \\
\text { lajlis and local } \\
\text { councils }\end{array}$ & $\begin{array}{l}\text { Targeted programs will be } \\
\text { adopted in each district and } \\
\text { city, and governors will } \\
\text { report to the public through } \\
\text { the media }\end{array}$ \\
\hline
\end{tabular}

Figure 1. Integrated approach and non-standard approaches to poverty reduction in Uzbekistan ${ }^{1}$

\footnotetext{
${ }^{1}$ Presidential Address: Priorities for 2021. -T.: “Development strategy”, 2020. - 7-8 p.
} 
According to the analysis, today the number of labor resources in Uzbekistan is about 19.2 million. people. This is 55.9 percent of the total population. $8.7 \mathrm{mln}$. or 45.3 percent of the population aged 16-29. If the unemployment rate in the country is $10.5 \%$ of the total labor force, a large part of it falls on the youth.

Indeed, the development of small business and entrepreneurship is the main factor and source in the employment of young people, their economic independence and finding their place in life. Therefore, the government pays great attention to the employment of young people and their preparation to be competitive in the labor market. In particular, about 230,000 young entrepreneurs and farmers, skilled craftsmen work in the country. The state is creating the necessary conditions for their further expansion.

More than 1.63 trillion soums of soft loans have been allocated for about 8,000 business projects of the younger generation within the Youth-Our Future program alone, as a result of which about 40,000 new jobs have been created.

Also, in order to attract more people to entrepreneurship and create additional conditions for legal employment, the President of the Republic of Uzbekistan on June 8, 2020 "On measures to simplify government regulation of entrepreneurial activity and self-employment" Resolution No. 4742 was adopted.

The list of "types of activities (works, services) for self-employed people" was approved by this decision. The list includes a total of 68 types of work and services, which have been granted a number of conveniences and benefits, and a mobile application has been developed for remote registration of their activities. In particular, previously selfemployed persons paid $1 \mathrm{mln}$. soums, now only 111.5 thousand soums have been paid for 2020 and have 1 year of work experience.

The experience of developed countries shows that entrepreneurship plays a vital role in modernizing and diversifying the national economy, ensuring its sustainable development, technical and technological reequipment, development of new types of products, is the main source of filling the domestic market with necessary goods and services. For Uzbekistan, the role of private entrepreneurship in the employment or selfemployment of the able-bodied population, increasing its income is especially important.

In this regard, when talking about the experience of European countries in the formation and development of the labor market, it would be expedient to consider, in particular, the Danish labor market policy.

From 1994 onwards, labour market policy in Denmark has been redesigned to include a more proactive and flexible approach to active labour market programmes as well as the concept of combining the fight against unemployment with the fulfilment of other goals, through leave schemes and job rotation. Part of the success in the Danish model can be attributed to a unique combination of flexibility in the employment relationship (indicated by a high level of labour and job turnover), the economic and social security of employees (illustrated by a generous unemployment benefit system) and the new labour market policy of activation (which upgrades the skills of the unemployed and thus support the ongoing transformation of the economy) - the elements that constitute the three corners of the Danish "golden triangle" (Madsen, 2003), (Figure 2). 


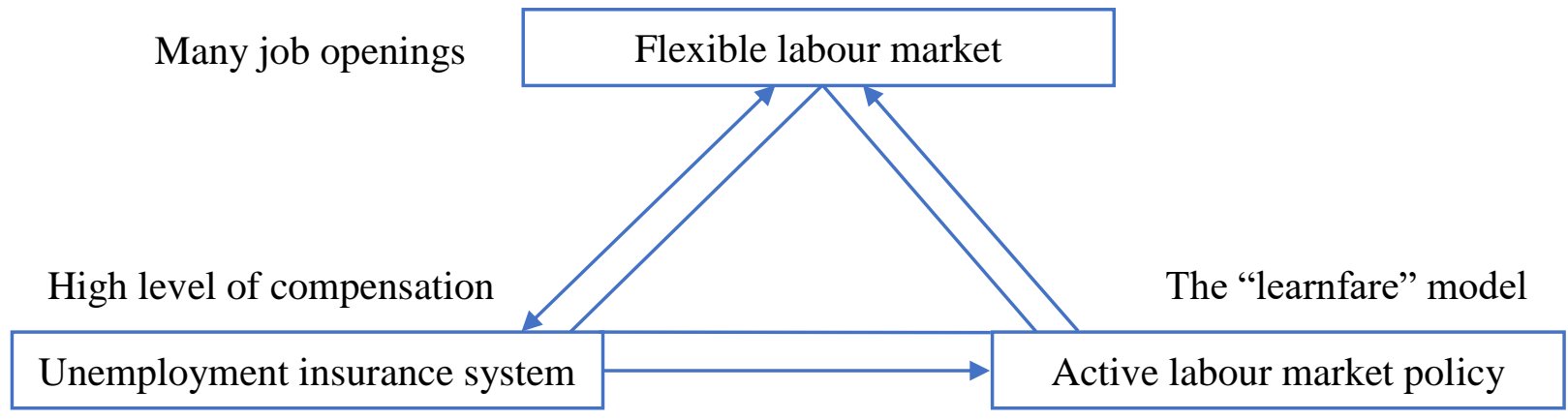

Figure 2. The Danish Golden Triangle

Of course, one of the key factors in ensuring the stability of the labor market is to pursue an active labor market policy in this country. Also, according to the experience of developed countries, the establishment of an unemployment insurance system is also a good way to finance the unemployment rate at the expense of the share of the worker during his employment. However, this will require the formation of a flexible labor market based on the creation of many jobs in the labor market, increasing the amount of compensation and improving the system of its payment.

\section{DISCUSSION OF RESEARCH RESULTS}

Based on the research, it should be noted that the country is carrying out a number of reforms to form the labor market, increase its flexibility and further development, and conduct research to study and solve problems in the field. However, this is not enough, there are a number of problems in the field:

- In the digital economy, it is necessary to improve the system of training for new professions and staff training;

- Solutions to the problems of increasing the efficiency of one-time or temporary employment of unorganized youth, the

population in need of employment and the unemployed exist only in theory, but in practice it is not given enough attention;

- The system of retraining of the unemployed with secondary and secondary special education to traditional and modern occupations, which are in high demand in the labor market in the short term, is not in demand;

- Based on combating bureaucratic and financial measures instead of improving 
the institutional framework for reducing informal employment;

- It is necessary to study the effective mechanism of state regulation of labor migration, etc.

We propose a mechanism to improve employment in order to improve the situation in the labor market and reduce unemployment, as well as to eliminate the above problems (Figure 3 ).

\begin{tabular}{|c|}
\hline Introduction of \\
new forms of \\
employment \\
taking into \\
account \\
demographic \\
changes \\
\hline
\end{tabular}
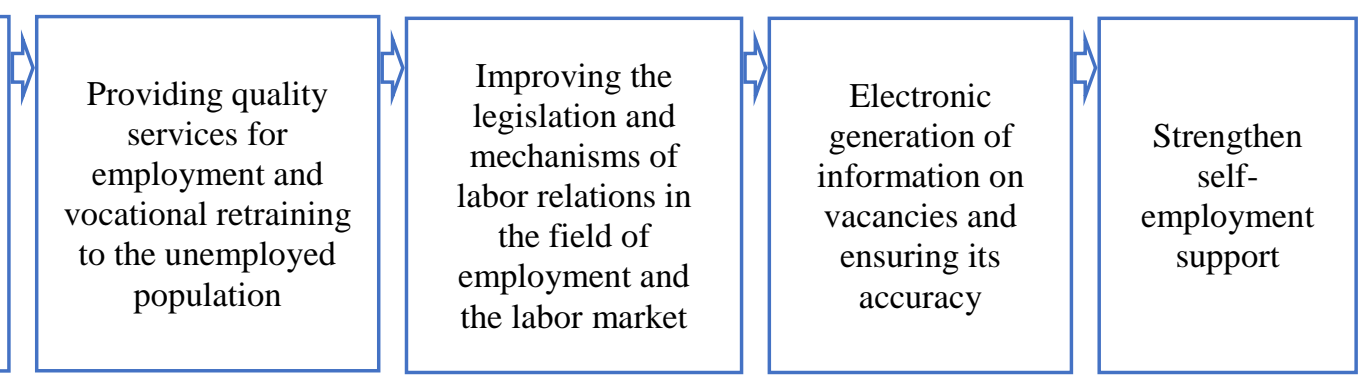

Figure 3. Mechanism for improving employment ${ }^{2}$

\footnotetext{
${ }^{2}$ Author's development.
} 
This mechanism will increase the number of new jobs based on demographic changes in the employment process, provide quality employment and retraining services, improve the legislation and mechanisms of labor relations, ensure the electronic formation and fairness of information on vacancies, as well as aimed at implementing more support for self-employment.

\section{CONCLUSIONS}

In shaping the labor market, its further development, reducing unemployment and ensuring the stabilization of employment, attention should be paid to the following areas:

1. Identify the characteristics of each region based on the location of the population and ensure the priority of measures taken in this direction;

2. It is necessary to create jobs in parallel with demographic changes, especially for the population with secondary and secondary special education;

3. It is necessary to pay attention to increasing the demand for additional jobs on the basis of improving the business environment, increasing

investment attractiveness and creating more opportunities for foreign investors;

4. It is necessary to improve the system of retraining for traditional and modern professions that are in high demand in the labor market;

5. It is necessary to introduce nonstandard forms of employment;

6. It is necessary to develop practical recommendations for improving programs for employment and job creation in the digital economy;

7. It is necessary to introduce an effective mechanism of state regulation of labor migration;
8. It is necessary to develop and organize a mechanism for organizing the unemployment insurance system.

In short, through the organization and development of the labor market is to ensure continuous improvement of employment and welfare of the population, the elimination of sharp differences in education, culture, skills, income, creating decent living conditions for people. Also, the active labor market policy is the essence of the reforms in the field, primarily focused on the person at the center of these changes, his personality and maturity. Therefore, it is necessary to increase the welfare of citizens, improve their living standards, to implement the principle, as the President said, "Reform is not for reform, but first and foremost to ensure the interests of man and his interests".

\section{REFERENCES}

1. Abdurahmonova G.Q. (2013). Employment in small business. Monograph. -T.: TDIU. -47 p.

2. Arabov N.U. (2017). Improving the analytical and information base for improving the efficiency and forecasting of labor market infrastructure // Scientific electronic journal "Economy and Innovative Technologies". Vol.5. - 2 p.

3. Henrekson M. (2014). How labor market institutions affect job creation and productivity growth // IZA World of Labor, Vol.38. - 2 p.

4. Korzhova D.A. (2015). Features of the formation of the labor market // "First independent scientific bulletin", Vol.1. $-89 \mathrm{p}$.

5. Lutfullaevich, Y. G. (2020). Impact of inflation on R\&D investment flow: Case of five Countries. International 
Journal of Scientific and Technology

Research, 9(1), 1970-1974.

6. Madsen P.K. (2003), "Flexicurity through labour market policies and institutions in Denmark" in P. Auer and

S. Cazes (eds.), Employment Stability in an age of flexibility; Evidence from industrialized countries, ILO: Geneva

7. Stytsyuk R.Yu. (2014). Methodological approaches to increasing the level of competitiveness of Russian organizations in the national and global markets // Russian Journal of Entrepreneurship. Vol.22. - 183-191 p.

8. Umarova M.A. (2019). Methodological bases of statistical forecasting of the labor market of the Republic of Uzbekistan. $\quad-T \quad \therefore$ Innovative Development Publishing House. - 22 p.

9. Kholmominov Sh.R. et al. (2016). Analysis of labor market development. Monograph. -T $:$ : "Science and technology". - $24 \mathrm{p}$.

10. Yunusov F. (2020). The COVID-19 pandemic and the fight against the global economic crisis: Uzbekistan's Strategy. -T $\quad . \quad$ "Development strategy". - 7-8 p.

11. Yakovets Yu.V. (2003). Globalization and interaction of civilizations. - M.: Economics. - $90 \mathrm{p}$.

12. www.stat.uz - Official site of the State Statistics Committee of the Republic of Uzbekistan.

13. www.mehnat.uz - Official site of the Ministry of Employment and Labor Relations of the Republic of Uzbekistan. 